\title{
As primeiras participações de atletas do hipismo sul-rio-grandense em Jogos Olímpicos
}

CDD. 20.ed. 796.08

798

http://dx.doi.org/10.1590/1807-55092015000100047
Ester Liberato PEREIRA*

Carolina Fernandes da SILVA*

Janice Zarpellon MAZO*
*Escola de Educação

Física, Universidade

Federal do Rio Grande do Sul.

\section{Resumo}

A prática do Hipismo no Rio Grande do Sul foi introduzida pela iniciativa de militares, posteriormente incorporada por civis. Gradualmente, os sul-rio-grandenses começaram a se destacar em competições esportivas. A questão norteadora deste estudo histórico é: como se desenvolveu a prática do hipismo em Porto Alegre até a primeira participação de atletas sul-rio-grandenses em Jogos Olímpicos. A análise documental das fontes evidenciou que a primeira participação de sul-rio-grandenses em Jogos Olímpicos, no hipismo, é datada de 1988, com a presença de um cavaleiro e de uma amazona, embora, desde a edição de 1948, já haver uma equipe representando o Brasil. A conquista de medalhas olímpicas ocorreu em 1996 e 2000, em equipes brasileiras contando com um sul-rio-grandense.

Palavras-Chave: Hipismo; História do esporte; Jogos Olímpicos; Clubes.

\section{Introdução}

O Hipismo é uma das práticas da Equitação ${ }^{a}$ o qual se constituiu em uma modalidade esportiva olímpicab, mas que também engloba atividades de lazer ${ }^{1}$. A organização do Hipismo transpôs obstáculos desde a institucionalização das primeiras associaçôes e entidades hípicas na cidade de Porto Alegre na década de $20^{2}$. A composição de tal panorama, futuramente, possibilitaria a emergência de atletas olímpicos.

O Hipismo porto-alegrense efetuou um de seus mais significativos saltos ao ver-se representado, pela primeira vez, na equipe brasileira que disputaria os Jogos Olímpicos de 1988 em Seul (Coréia do Sul). Anos mais tarde, a consolidação do Hipismo sulrio-grandense foi confirmada com a conquista de duas medalhas olímpicas para o Brasil, nas ediçóes dos Jogos Olímpicos de 1996, em Atlanta (Estados Unidos), e de 2000, na cidade de Sidney (Austrália). Além disto, o que também reforça a conquista da condição atual da capital do Estado como um dos palcos olímpico do Hipismo, é o fato de Porto Alegre sediar, anualmente, dois dos principais eventos do calendário nacional deste esporte: o Festival Hípico Noturno da Brigada Militar, o mais antigo evento hípico noturno do paísc, e o The Best Jump ${ }^{\mathrm{d}}$, evento internacional que abrange uma Copa das Naçóes, além de ser válido como classificatória para a Copa do Mundo de Hipismo e para os Jogos Pan-Americanos.

As disciplinas equestres reconhecidas pela Confederação Brasileira de Hipismo (CBH), de acordo com a Federação Equestre Internacional (FEI), são: Rédeas, Volteio, Enduro, Atrelagem, Saltos, Adestramento, Concurso Completo de Equitação (CCE) e Especial (paralímpica). Todavia, os esportes que integram o programa dos Jogos Olímpicos de Verão ${ }^{\mathrm{e}}$ são os seguintes: Saltos, Adestramento, Concurso Completo de Equitação (CCE). Com relação aos Jogos Paralímpicos de Verão, a modalidade do Hipismo está representada pela prática do Adestramento Paraequestre ${ }^{3-4}$.

Conforme Vieira e Freitas ${ }^{3}$, a modalidade do Salto constitui a prática mais divulgada do Hipismo. Isto se confirma a partir das fontes consultadas, nas quais o Salto foi a prática destacada, havendo silêncios sobre as demais práticas componentes do Hipismo. O Salto do Hipismo consiste em uma prova realizada em pista de areia ou grama, na qual o conjunto, composto pelo atleta e cavalo, deve transpor de 10 a 15 obstáculos, com o intuito de finalizar a passagem 
sem cometer faltas como, por exemplo, sem derrubar nenhum obstáculo, no menor tempo possível ${ }^{3}$.

Contudo, longe de reduzir tal prática esportiva às referidas circunscriçóes, ofuscando sua variedade, a definição apresentada anteriormente tem o intuito apenas de fornecer uma breve ideia do que trata o Salto do Hipismo. Isto porque partilhamos do pensamento de BuRKE ${ }^{5}$, que elucida a compreensão das práticas culturais, tais como o esporte, o qual não pode conformar-se com a limitação a um conceito prévio e rigidamente estabelecido. Nesta direção, concebe-se o Salto do Hipismo como uma prática da qual emergem representaçóes culturais, que conformam um imaginário acerca dessa modalidade esportiva peculiar à apropriação que lhe é conferida de acordo com o contexto histórico e sociocultural a que esteja associada.

Diante destas consideraçóes, a questão norteadora deste estudo histórico é: como se desenvolveu a prática do Hipismo em Porto Alegre até a primeira participação de atletas sul-rio-grandenses em Jogos Olímpicos. Identificar as representaçóes esportivas que se construíram sobre tal prática implica em compreender como o passado foi sendo ressignificado e as plausíveis explicaçóes para as manifestaçôes deste esporte olímpico no presente. Assim, tem-se que o presente não é a soma dos passados, mas guarda suas especificidades, seus próprios condicionamentos, que, possivelmente, só entender-se-á melhor, pelo menos historicamente, em algum momento futuro. É inegável que o presente e o passado guardam uma relação, e a escrita da História é sempre uma busca de verdades e uma elaboração de versóes sobre os

\section{Método}

Para a realização desta pesquisa, foram consultados jornais e revistas arquivados em diferentes acervos. O jornal "A Federação", acessado na Hemeroteca da Biblioteca Nacional Digital, consistiu em um dos veículos de exposição dos ideais políticos do Partido Republicano Rio-grandense (PRR). Este jornal produzido em Porto Alegre, cuja primeira edição começou a circular no mês de janeiro de 1884, expunha assuntos políticos acoplados ao Estado e ao Brasil, além de acontecimentos policiais e alguns anúncios. No início do século XX, "A Federação" se atualizou, abandonando o caráter exclusivamente político e econômico e abordando assuntos sobre o esporte, dentre esses o turfe e o hipismo e artes, além de dar traços do passado por meio das fontes acessadas e dos conceitos analisados. Assim, segundo PesavenTo $^{6}$, a História está habilitada a "lançar luz", dialogando com outras disciplinas, em busca de uma compreensão maior, sem a pretensão de estabelecer "verdades absolutas".

Conforme Воотн ${ }^{7}$, a abordagem da História Cultural questiona os princípios analíticos e empíricos da história modernista e a sua reivindicaçáo de fornecer explicaçôes verdadeiras e objetivas, especialmente das relaçóes entre causas e efeitos. Os pensamentos pós-modernos reverberam pela História do Esporte contemporâneo e alimentam muito do paradigma cultural. Para contemplar a questão norteadora do estudo buscou-se apoio na perspectiva da Nova História Cultural e no campo da "História do Tempo Presente" ${ }^{\text {, }}$ na qual os fatos ainda estão a se desenvolver, pois é uma História ainda não findada, impossibilitando ao pesquisador reconstruir um processo finalizado, do qual já se conhecem o fim e as consequências.

Por meio deste estudo, também se procurou contribuir para a reflexáo sobre como se processa a fabricação da memória esportiva e do seu esquecimento, enquanto estratégia de presentificar ausências $^{6}$. No caso do Hipismo, trata-se de evidenciar no tempo e espaço, as sociabilidades que pautaram o desenvolvimento desta prática, que foi organizada por certos grupos sociais, os quais construíram pertencimentos e relaçóes de identidades e alteridades ${ }^{8}$. Estes grupos produziram manifestaçóes culturais, construindo estratégias e, assim delimitando quem são os integrantes e os excluídos. destaque aos anúncios comerciais. Foi extinto em 1937, mas, felizmente, exemplares do jornal foram preservados, permitindo a pesquisa documental.

O jornal "Zero Hora" é parte do acervo pessoal de uma das pesquisadoras. Foi selecionado para compor o "corpus" documental da pesquisa pelo significativo número de reportagens acerca dos cavaleiros brasileiros que compuseram equipes olímpicas de Hipismo, em especial os cavaleiros sul-rio-grandenses. Este jornal porto-alegrense, que circula desde o ano de 1964, está na listagem dos maiores jornais de circulação cotidiana no país, ocupando atualmente a sexta posição nacionalf.

Publicaçôes do jornal "Diário de Notícias" encontrados no Museu da Comunicação Hipólito Social 
José da Costa também se constituíram em fontes impressas do estudo, pois destinou mais espaço em reportagens sobre a prática do Hipismo. Este jornal foi criado no ano de 1925, em Porto Alegre, e, posteriormente, operou em consonância com a TV Piratini (precursora no Estado), Rádio Farroupilha e Revista Campos. O último exemplar do Diário circulou em 30 de dezembro de 1979.

O jornal "Correio do Povo"h, fundado em 1895 , consiste no mais antigo jornal na capital sulrio-grandense, ainda em circulação. No período demarcado da pesquisa, era um jornal de grande destaque, trazendo muitas notícias sobre as práticas equestres; dentre estas, o turfe e o hipismo figuravam frequentemente em suas páginas, demonstrando a evidência destas na sociedade da época. No entanto, um maior destaque era conferido ao turfe.

A revista consultada foi a "Revista do Globo", que se trata de um destacado quinzenário editado no Estado do Rio Grande do Sul pela Livraria Editora Globo por quase quatro décadas, do ano de 1929 a 1967. Conforme Torres ${ }^{9}$, a Revista do Globo reforça a imprensa porto-alegrense e preenche uma lacuna deixada por fracassados periódicos do mesmo tipo. Esta revista, por meio de seus 943 exemplares publicados ao longo de quase 40 anos divulgou, entre outros, assuntos de literatura, arte, moda, cinema e esportes. Em sua primeira ediçáo, no mês de janeiro de 1929, a revista já publicou reportagens sobre práticas esportivas. Dentre os esportes que tiveram reportagens veiculadas na referida revista, encontram-se as práticas equestres, principalmente o turfe e o hipismo, as quais foram acessadas por meio do Catálogo "O Esporte e a Educação Física na Revista do Globo (1929-1967)”, elaborado por $\mathrm{MAzO}^{10}$.

A revista "Equusul", por sua vez, foi localizada no Museu da Brigada Militar em Porto Alegre. Esta revista emergiu, em 1989, com o desígnio de promover toda e qualquer atividade realizada no
Rio Grande do Sul relacionada aos cavalos. Contudo, poucas reportagens desta revista abordavam a temática da presente pesquisa.

Já a revista "Santo Amaro a Galope", constitui-se em uma publicação "online" e está disponível no "site" do Clube Hípico de Santo Amaro, localizado em São Paulo. Originalmente, começou a ser publicada em formato impresso, em 1982, com o intuito de aprimorar o diálogo entre a diretoria do clube e os associados.

O "Almanaque Esportivo do Rio Grande do Sul" foi organizado por José Ferreira Amaro Júnior, no período de 1942 a 1959. Há algumas reportagens destacando o hipismo e o turfe nesta publicação.

Assim, de maneira geral, foram encontrados, aproximadamente, 110 artigos com referências ao hipismo. Em um primeiro momento, este conjunto documental foi submetido a uma "análise de adequaçáa" 11 com vistas a verificar se as fontes propostas realmente estarão sintonizadas com o problema histórico proposto. A partir disso, dentre as fontes levantadas para este artigo, foram utilizadas: $12 \mathrm{da}$ Revista do Globo; quatro do Diário de Notícias; duas da Zero Hora; uma do A Federação; duas da Equusul; uma do Correio do Povo e uma do Almanaque Esportivo do Rio Grande do Sul.

Após a fase da coleta das fontes, passou-se para a codificação das informações recolhidas. As notícias coletadas em cada tipo de fonte foram fichadas e classificadas a partir do editorial, da reportagem e do conteúdo. Os critérios utilizados para o registro e a organização das informaçóes foram definidos a partir dos assuntos: Hipismo e Hipismo nos Jogos Pan-Americanos e nos Jogos Olímpicos. Em seguida, as informaçóes foram submetidas à técnica de análise documental, conforme os termos descritos por BACELLAR $^{12}$. Na sequência, houve o cruzamento das fontes e os resultados da interpretação das informaçôes confrontadas são expostos nos tópicos que seguem.

\section{Resultados e discussão}

\section{O pioneirismo militar na prática do hipismo em Porto Alegre}

Neste tópico, é abordado o pioneirismo militar na prática do Salto do Hipismo em Porto Alegre, pois os primeiros indícios localizados nas fontes denotam a iniciativa da Brigada Militar - como é denominada a polícia militar do Rio Grande do Sul. Esta prática imprimiu seus primeiros passos oficiais na região pela iniciativa da Escolta Presidencial, criada em 25 de janeiro de 1916, por meio do Decreto-Lei n. 2.172, a qual passava a constituir uma nova unidade da Brigada Militar. A Escolta Presidencial, constituindo uma unidade autônoma da corporaçáo da Brigada Militar, tinha por missão principal exercer o serviço de guarda, vigilância e segurança do palácio do governo do 
Estado e realizar a segurança pessoal do Presidente da Província - atual governador do Estado. Esta Escolta, a fim de melhor preparar e condicionar seus cavalos e cavaleiros para exercer tais funçóes, desenvolvia a prática do Hipismo. Os integrantes desta milícia sul-rio-grandense, que executavam tais tarefas, eram denominados Dragóes Farroupilhas e pertenciam, originariamente, ao esquadrão destacado do Primeiro Regimento de Cavalaria da Brigada Militar, situado na cidade de Santa Maria, na região central do Rio Grande do Sul ${ }^{13}$. Por meio desta alcunha, verifica-se o caráter de força e regionalismo que caracterizava estes cavaleiros militares.

O serviço propriamente dito dos Dragóes Farroupilhas não foi muito diferente daquele executado antes da criação da Escolta Presidencial. Todavia, cabe ressaltar que a imponência de suas vestimentas conferia destaque nos desfiles realizados nas comemoraçóes cívicas. Quando designado oficialmente, este grupo passou a ter a importância de uma unidade da Brigada Militar, inaugurando sua primeira sede no Bairro Cristal, na capital do Estado.

Desde o final do século XIX, o crescimento da cidade expandia-se em direção ao Bairro Cristal como parte de seu processo de urbanizaçáo. De forma modesta, um dos primeiros sinais de tal urbanizaçáo, deu-se por meio da instalação da Hospedaria para Imigrantes', em 1891, localizada onde atualmente situa-se o Hipódromo do Cristal. Todavia, este edifício acolheu os estrangeiros somente por um breve período de tempo. Oito anos mais tarde, em 1899, parte deste abrigo foi requisitado com o intuito de acampar o $3^{\circ}$ Batalhão de Infantaria da Brigada Militar. Em 1916, a Escolta Presidencial também é instalada neste espaço. Ao encontro desta informação, RIBEIRo ${ }^{14}$ menciona a vigência de um regimento de cavalaria da Brigada Militar no Bairro Cristal já no ano de 1918.

Com o passar dos anos, a Escolta Presidencial sofreu modificaçóes e teve o seu efetivo paulatinamente aumentado até que, em cinco de janeiro de 1922, já contava com 136 homens na unidade. A partir de entấo, evidenciaram-se alguns feitos da Escolta Presidencial como, por exemplo, em 18 de novembro de 1923, quando uma diligência composta por 20 homens e comandada pelo alferes Camilo Diogo Duarte marchou para o município de Viamão a fim de combater uma quadrilha que perturbava aquela localidade. Neste momento, a esfera de atuação da Escolta Presidencial estava transposta: a unidade começava a atuar na manutenção da ordem pública.

Além da incorporaçáo de mais uma tarefa no seu quadro de açóes, a Escolta Presidencial também teve sua localização alterada, apesar de certa imprecisão nas fontes consultadas com relação ao período em que isto ocorreu. A mudança de sua sede efetuou-se para o Quartel das Bananeiras, na Chácara das Bananeiras, na antiga Rua Dois Irmãos, atual Avenida Coronel Aparício Borges, n. 2351, em Porto Alegre, onde se encontra o atual $4^{\circ}$ Regimento de Polícia Montada da Brigada Militar ou Regimento Bento Gonçalves (RBG). Tal denominação é uma homenagem ao patrono do regimento, o general Bento Gonçalves da Silva, considerado um importante combatente da Revoluçáo Farroupilha (1835-1845).

Em fontes de pesquisa, como a Revista do Globo $^{10}$, são apresentadas imagens de cavaleiros e cavalos praticando o Salto do Hipismo em torneios hípicos na então regiáo da Chácara das Bananeiras em 1929. Ao mesmo tempo o livro sobre o histórico do $\mathrm{RBG}^{15}$ aponta a mudança do regimento do Bairro Cristal somente no ano de 1945 para a nova localidade (atual Bairro Coronel Aparício Borges, onde a sede situa-se até hoje). Tendo em vista estas informações, pode-se considerar que até 1945 , as atividades hípicas que ocorriam na Chácara das Bananeiras tratavam-se apenas de competiçóes equestres, enquanto que a sede da Escolta Presidencial mantinha-se no Bairro Cristal. Apresentando mais indícios nesta direção, Pimentel ${ }^{16}$ afirma que o Bairro Cristal ainda contava com "seu tradicional quartel” (p.599) no ano de 1945.

Independentemente da localizaçáo exata da escolta, as informaçóes ratificam que a prática do Salto do Hipismo tem seus primórdios, em Porto Alegre, associada ao contexto militar. Era restrita somente aos policiais e oficiais militares, reportando às possíveis origens de desenvolvimento deste esporte ao nível mundial. Posteriormente, expande-se também para a parcela civil da população.

Os primeiros indícios da existência de uma associação que, além de promover a prática do Salto do Hipismo, permitia o acesso de pessoas do meio civil de Porto Alegre a este esporte foram localizados na Revista do Globo ${ }^{10}$. Nesta fonte de pesquisa, identificou-se a fundação, em 1925, da Sociedade Hípica Rio-Grandense. Os indícios identificados em nossas fontes sugerem a presença de civis da elite econômica da cidade e militares dentre os fundadores de tal associação. Também há indicativos de que, a frente deste grupo que instituiu tal sociedade, encontrava-se um representante militar ${ }^{17}$.

Além disso, percebeu-se, na reportagem, que o Salto do Hipismo não encontrava resistência em compor parte das atividades de instrução das 
mulheres, em especial daquelas pertencentes às camadas ligadas às elites econômicas. As festas hípicas realizadas no Campo da Redenção (atual Parque Farroupilha) ${ }^{18}$ costumavam contar, além da presença de militares do Exército e da Brigada Militar, com a significativa presença das mulheres nas disputas a cavalo, na década de $30^{19}$. O Hipismo, associado a mais de um grupo cultural de origem europeia em Porto Alegre - os quais trouxeram os influentes ideais das lutas das mulheres e apresentando novas perspectivas para as brasileiras - propunha uma nova expectativa à participação social das mulheres das elites econômicas, compondo parte de sua educação ${ }^{20}$. Tal fato pode estar relacionado à concepção desta prática esportiva como um elemento do ensino das jovens das elites, além de consistir em um sinal de "status" e distinção, um saber, uma capacidade. Além de as fontes históricas não ocultarem que tal prática era somente acessível aos detentores de capital social e econômico, elas também realçavam e reforçavam tal distinção por meio do emprego de termos tais como: "elegante", "elite porto-alegrense", "figuras destacadas da sociedade gaúcha"18,21-22.

Outro aspecto a destacar, refere-se a um processo de esportivização, mais especificamente a uma especialização de funçóes, que foi identificado no contexto do Hipismo desde seus primórdios. Emerso no ambiente de caserna, na Brigada Militar, em Porto Alegre, o Salto do Hipismo, desde seus primórdios, já demandava mais funçôes além dos oficiais cavaleiros, os quais se dedicavam à prática. Eram necessários ferradores para a manufatura de ferraduras e a aplicaçáo das mesmas nos cavalos; seleiros para confeccionar artigos para a prática, tais como selas de couro, rédeas, arreios, dentre outros. Além disto, eram demandados, também, instrutores, os quais, predominantemente, neste período, provinham do meio militar e, muitas vezes, eram estrangeiros que traziam sua experiência da equitação de referência militar europeia ${ }^{22}$.

O exército, por sua vez, dentre seus eventos hípicos, realizava a Semana do Cavalo de Guerra. Esta era mais uma oportunidade de integração de autoridades políticas e militares, como prefeitos, generais e comandantes ${ }^{23}$. Também chamada de Campeonato Nacional Cavalo D'Armas ${ }^{k}$, a Semana do Cavalo de Guerra congregava competidores militares do exército e da Brigada Militar. Uma das provas realizadas neste campeonato era a "steeple-chase" - um tipo de corrida de cavalos com obstáculos a transpor, semelhante ao atual Concurso Completo de Equitação $(\mathrm{CCE})^{1}$-, o qual era realizado no Hipódromo da Associação Protetora do Turfe ${ }^{24}$.
Na prática do Salto do Hipismo, em Porto Alegre, também há indícios de um caminho tecnológico da quantificaçáo na década de 30 , quando os certames entre a Sociedade Hípica Porto Alegrense ${ }^{\mathrm{m}}$, o Porto Alegre Country Club e a Brigada Militar eram decididos com base no tempo e na quantidade de faltas cometidas pelos conjuntos cavaleiros-cavalos. Como exemplo, tem-se um concurso equestre promovido pela Sociedade Hípica Porto Alegrense, em 1939, no então Campo de Polo da Várzea (atual Parque Farroupilha). O aspirante da Brigada Militar Vasco de Melo Leiria é apresentado, em reportagem da Revista do Globo, como vencedor da prova principal desta disputa, "[...] tendo coberto o percurso em 55 s $2 / 5$, com 1 falta" 25 (p.48).

Este tipo de ocorrência nas práticas esportivas da cidade sugere uma relaçáo com o contexto de uma cidade que se contagiava pelos ares da modernida$\mathrm{de}^{26}$, com padróes e valores de diversas metrópoles, onde um novo homem e uma nova mulher viriam a emergir. Deste modo, as trajetórias dos produtos e símbolos da modernidade, das sociedades urbanas e industriais, se entrelaçam e se confundem. A prática esportiva se alarga na mesma velocidade com que se desenvolvem bairros e cidades industriais, refletindo uma nova organização social do trabalho, por meio da disciplina - pela demarcaçáo das regras, do controle do tempo e da hierarquia - da especialização das funçóes e o trabalho coletivo, em contraposição à configuração artesanal do trabalho; da quantificação dos resultados e da competitividade ${ }^{26}$.

No contexto hípico porto-alegrense, há indícios de recordes já desde as primeiras décadas do século XX, mais especificamente desde a década de $30^{25}$, pois havia a quantificação e registro do número de conquistas de títulos em competiçóes. É o caso, por exemplo, do Coronel Gerson Borges, da Brigada Militar, sendo o "[...] cavaleiro que possui o maior número de títulos na equitação nacional”27 (p.20, grifo nosso).

Verifica-se que o cavaleiro porto-alegrense de destaque pertencia à instituição responsável pelos primeiros passos de caráter mais oficial do Salto do Hipismo na cidade: a Brigada Militar. Possivelmente, tal fato pode estar relacionado com uma estruturação mais sólida da formação e instrução equestres proporcionadas aos integrantes da corporaçáo militar.

As sociedades hípicas e o governo do Estado de São Paulo, também reconheciam o Coronel Borges como o cavaleiro diferenciado do Hipismo nacional. Uma homenagem foi prestada a ele no final da década de 80, pelo Departamento Hípico do clube Farrapos de Porto Alegre, o qual criou a Copa de 
Hipismo Cel. Gerson Borges ${ }^{28}$. Este evento passou a constituir o calendário hípico do Rio Grande do Sul, concedendo aos vencedores (poderia ser disputado apenas por equipes) o troféu de mesmo nome, cuja posse decisiva do prêmio seria concedida à equipe que vencesse o torneio por três anos sucessivos ${ }^{\mathrm{n}}$.

A instituição do campeonato pelo clube Farrapos também pode estar relacionada com o fato da associação congregar os oficiais da Brigada Militar. Desta forma, para além de uma homenagem à destacada atuação do Coronel Gerson Borges como cavaleiro sul-rio-grandense, estaria implícito o tributo a um oficial e atleta integrante da Brigada Militar. Imagens localizadas no Museu da Brigada Militar também reforçam a quantidade de vitórias alcançadas pelo atleta, especialmente nas décadas de 30 e 40 . Este atleta militar destacou-se, inclusive, em provas internacionais, como no Uruguai. Somadas as conquistas, por meio da quantificação e dos recordes, estabelecese a oportunidade de qualquer cavaleiro/amazona posterior ao Coronel Gerson Borges disputar com o mesmo pelo maior número de vitórias atingidas por um atleta sul-rio-grandense do Hipismo.

Observa-se que, no contexto do Salto do Hipismo porto-alegrense, os recordes são registrados por meio do destaque às conquistas do cavaleiro/ amazona, ao passo que, no turfe da cidade, as marcas de recorde são armazenadas pelos êxitos dos cavalos. Isto corrobora com o que $\mathrm{MeLO}^{29}$ afirma com relação à prática turfística no Rio de Janeiro: "No turfe, sempre se divulgava o nome e a vitória dos cavalos; [...] o crack era o cavalo [...]"29 (p.8), isto é, quem vence a corrida é um cavalo que tem um homem como coadjuvante.

Em Porto Alegre, as fontes revelaram que houve um paulatino processo de expansão do acesso à prática do salto do hipismo, inicialmente mais restrita ao âmbito militar, e, posteriormente, acessível também à parcela civil da sociedade. Somente após quase uma década da criação da Escolta Presidencial, e do consequente início da organização da prática do salto do Hipismo em Porto Alegre, é que se registrou a fundação de uma sociedade promotora deste esporte para indivíduos do meio civil, a Sociedade Hípica Rio-Grandense (1925).

\section{A presença dos civis no hipismo}

A Sociedade Hípica Rio-Grandense tinha como símbolo a figura de um cavalo entre uma ferradura, imagem que sugere que o cavalo constituía o cerne de suas atividades. Ao encontro deste pensamento, alia-se o fato de que todas as suas atividades esportivas envolviam a participação conjunta com este animal, ou seja: dentre as práticas esportivas promovidas, encontravam-se somente aquelas de caráter equestre. Os torneios de saltos, partidas de polo equestre, volteio ${ }^{\circ}$, "crosscountry" ", e o antigo costume que, possivelmente, consistiu em uma das origens do hipismo, a caçada à raposa, faziam parte das denominadas Temporadas Desportivas da SHR. Estes eventos costumavam integrar militares e civis em nome do esporte ${ }^{30}$, os quais compunham o quadro de sócios desta entidade ${ }^{31}$ (p.2). Há também registros da presença do ex-presidente Getúlio Vargas em suas tribunas oficiais ${ }^{10}$.

A prática do Hipismo, para além dos ambientes militares e da SHR, no princípio da década de 30, começou a ser oferecida pela primeira vez por uma associação esportiva já existente em função de outra prática esportiva: o Porto Alegre Country Club, instituído em função do interesse de um grupo de homens na prática do golfe. Posteriormente, em 1939, a Sociedade Hípica Porto-Alegrense foi fundada e configurou-se como um espaço em que, mais do que oferecer a prática hípica, tinha nesta a essência de sua organização.

Assim, na década de 30, o hipismo já era promovido pelas seguintes entidades: Sociedade Hípica Rio-Grandense, Porto Alegre Country Club e Sociedade Hípica Porto-Alegrense, além da já existente Brigada Militar. Posteriormente, muitos integrantes da Sociedade Hípica Rio Grandense passaram a compor o quadro de Equitação do Porto Alegre Country Club, quando da sua provável fusáo, em 1934. Tal departamento hípico, próximo à década de 50, passou a integrar a Sociedade Hípica Porto Alegrense, que, neste momento, contava, pela primeira vez, com uma sede própria, na zona sul da cidade, a qual é vigente até os dias atuais.

Reportagens da Revista do Globo registram a presença deste esporte nas associaçóes: "A Sociedade Hípica Porto Alegrense proporcionou [...] um espetáculo magnífico aos esportistas da cidade [...] realizando um concurso equestre"25 (p.48). Tal informação sugere que a prática do salto do hipismo e seus eventos, em Porto Alegre, neste período, eram valorizados como entretenimento pessoal, uma peculiaridade associada por $\mathrm{DAMO}^{32}$ ao esporte amador, em particular como ocorreu no caso do futebol.

O hipismo, assim, desde o início do século XX, limitava-se à esfera amadora, tanto com relação aos seus praticantes como a seus espectadores, uma vez que todos estes se encontravam ligados à classe com maior poder econômico da cidade, a qual, como 
no caso da assistência do turfe, primava pelo puro prazer e liberdade da prática em si, sem a existência de qualquer forma de remuneração ou incentivo material. Nos espaços hípicos da cidade, se realizavam inúmeras festas hípicas contando com a presença de importantes e destacados membros da sociedade da época, ladeados por autoridades, passando a constituir outro ambiente de diversão e lazer.

$\mathrm{Na}$ capital, no período das décadas de 20 e 30 , consolidaram-se melhorias, tais como bondes elétricos, cafés, cinemas e automóveis; entretanto, estes não contemplavam a todos os grupos sociais. O Plano Geral de Melhoramentos, um primeiro movimento organizado de modernização da cidade, idealizado por João Moreira Maciel, da Diretoria de Obras da Intendência, em 1914, e implantado a partir de 1924, previu avenidas, bulevares e rótulas, procurando tornar Porto Alegre semelhante a Paris ${ }^{33}$. Além deste espelhamento europeu, há outros, como a prática do salto do hipismo, pois há evidências de que este esporte tenha vindo na bagagem cultural de imigrantes ingleses, bem como de imigrantes alemães.

Além disto, conforme $\mathrm{MeLo}^{34}$, o hipismo fazia parte das práticas esportivas que, no início do século $\mathrm{XX}$, eram consideradas como sinais de "status" e distinção, marcas de classe e hierarquia social. A Revista do Globo, ao publicar na década de 40 a divulgação da organização de uma temporada hípica, realçou que as associaçóes esportivas que a promoveriam "[...] congregam figuras destacadas da sociedade gaúcha [...]"22 (p.38). Nesta medida, homens, mulheres e crianças já são vistos como protagonistas nas imagens desta prática esportiva. Inclusive, a equitação era concebida como parte da educaçáo de mulheres jovens das elites, sendo apreciada em funçáo de que elas deveriam desenvolver determinadas capacidades que lhes consentissem satisfazer com propriedade os novos papeis sociais esperados. Na prática equestre do hipismo, era mais trivial e mais plausível a participação das mulheres, especialmente das elites, as quais já tomavam parte ativa nas competiçôes.

Com o início do Estado Novo (1937), as práticas esportivas passaram a desempenhar um papel relevante no contexto da política nacional brasileira ${ }^{35}$. Até então, houve a propagação das associaçôes esportivas sem um controle mais significativo do poder público. Perante este cenário, em 1941, foi promulgado o Decreto-Lei n. 3199, o qual buscava regulamentar o esporte nacional.

No cumprimento da exigência legal, em 1943, era fundada a Confederaçáo Brasileira de Hipismo $(\mathrm{CBH})$, e, somente três anos mais tarde, em 1946, foi criada a Federação Hípica Sul Rio-Grandense (FHSRG), em Porto Alegre. A nova organização esportiva no hipismo abalizava reflexos da referida lei $^{36}$ que suscitaria alteraçóes na maneira como a prática hípica vinha desenvolvendo-se, tanto na capital como no Estado, desde sua emergência.

A este respeito, em reportagem do Almanaque Esportivo do Rio Grande do Sul ${ }^{37}$, encontra-se o registro de um acentuado desenvolvimento da prática do hipismo, no Estado, em 1946. Apesar de se considerar que este referido ano é o mesmo da fundação da FHSRG, o texto ainda destaca que foi somente em 1947 que esta nova entidade hípica entrou em atividade completa. Portanto, os avanços conquistados na prática do hipismo deviam-se, especialmente, ao esforço dos clubes que o promoviam, bem como de seus adeptos. Desta forma, a reportagem ainda apresenta o hipismo como "o esporte predileto do gaúcho" ${ }^{37}$ (p.183), reforçando, assim, o incremento crescente deste esporte na década de 40 , com os clubes porto-alegrenses que o proporcionavam, destacando-se a Sociedade Hípica Porto Alegrense, o Clube Farrapos e o Clube Hípico Andrade Neves. Tal consolidação do hipismo deu-se, principalmente, por meio da regularidade com que já eram realizadas competiçóes, as quais contavam com um número cada vez mais elevado de competidores e público.

Ao traçar um paralelo entre Porto Alegre e a cidade do Rio de Janeiro, pode-se perceber que a prática do hipismo estruturara-se de forma sistemática e anterior na capital do país na época, aproximadamente na primeira metade do século $X X^{q}$. No início do século XX, o Rio de Janeiro já contava com três centros hípicos e muitas competiçóes eram organizadas, apesar da pouca popularidade e da significativa circunscrição à esfera das elites ${ }^{38-39}$. Tal conjuntura pode estar relacionada ao fato de que, entre 1863 a 1865, foi instalada, na entáo capital do Brasil, a Escola de Equitação de São Cristóvão, importando os princípios equestres europeus ${ }^{40}$.

Já na cidade de São Paulo, por sua vez, apesar do período de transformaçóes que atravessava, conforme GordinHO ${ }^{41}$, o costume da equitação, do passear a cavalo, continuava vigente entre os paulistanos - obviamente, assim como no Rio de Janeiro, neste período, a prática seguia entre os mais abastados, que podiam adquirir animais com um alto valor financeiro. Esta circunstância propiciou que, já no início da segunda década do século XX, fosse fundada a Sociedade Hípica Paulista, em 1911.

Faz-se imperativo relacionar o cenário do hipismo em Porto Alegre com o do Rio de Janeiro e de São 
Paulo em funçáo de que estas cidades possuíam uma projeção econômica, valor político, emblemática proeminência e dinâmica cultural ${ }^{42}$. Desde o princípio da República, constituíram núcleos de ampla importância e referência nacional, em todos os campos, e colaboraram, decisivamente, para a constituição deste panorama. Porto Alegre, por sua vez, só passou a contar também com uma sociedade hípica 14 anos mais tarde do que Sáo Paulo, por ocasião da fundação da $\mathrm{SHR}$, a qual passou a proporcionar, formalmente, o acesso a esta prática equestre também à população civil da cidade.

\section{Hipismo: um esporte de classe e distinção social}

As características da caça à raposa, apresentadas por Elias e Dunning ${ }^{43}$, a sugerem como uma das prováveis origens da prática do Salto do Hipismo, e determina o que seria considerado o adequado esporte, isto é, aquele vinculado a um "ethos" peculiar: o das elites econômicas e sofisticadas da Inglaterra do século XVIII. Para tais classes, a tensão e a excitação proporcionadas pelo prazer da perseguição da raposa, a cavalo, percorrendo um percurso pleno de obstáculos, foram valorizadas para se organizarem como componente central da atividade de distração do Hipismo. Isto nos sugere que os saltos da prática do Hipismo, limitados por uma pista, passam a remontar aos momentos em que os cavalos precisavam saltar troncos, riachos e outros obstáculos que os caçadores encontravam pelas florestas.

O gosto pela Equitação se instituiu de tal maneira que, também em tempo de baixa estaçáo de caça ou em períodos de inverno severo, os britânicos se organizavam para o exercício dos saltos, revelando primitivos vestígios daquela que se tornaria a atividade mais apreciada do Hipismo, ou seja: os Saltos. A elite econômica inglesa proprietária de terras, instituiu uma maneira culturals de caçar que se distinguia de outras e balizava seus praticantes como uma parte distinta da sociedade; portanto a caça à raposa pode ser considerada uma prática de distinção social.

No que tange ao Rio Grande do Sul, há indícios de que a prática da caça à raposa tenha ocorrido no Estado; mas, para, além disto, foi apropriada de uma forma muito peculiar. De acordo com reportagens da Revista do Globo ${ }^{44}$ e do jornal Diário de Notí$\mathrm{cias}^{45}$, um cavaleiro ou uma amazona, montado (a) em um cavalo, desempenhava a função de "raposa" durante a prática, sendo o (a) único (a) conhecedor (a) do percurso da caça. A função de "raposa" exigia a demonstração de muitas habilidades intrínsecas à Equitação para poder fugir dos demais cavaleiros e amazonas candidatos a "caçá-lo (a)", isto é, alcançálo (a) e tocá-lo (a) em meio à fuga a galope (andadura do cavalo de alta velocidade).

Outro importante indício de que os primórdios do Salto do Hipismo tenham relação com elementos da caça à raposa são anunciados por ADELMAN ${ }^{46}$ : a participaçáo civil neste tipo de caça e a presença de mulheres que aderiam a esta prática sobre os cavalos. Faz-se a ressalva que estas características - participação civil/militar e presença de homens e mulheres na mesma competição -, estão presentes no Salto do Hipismo até os dias atuais.

O estudo de Vigarello ${ }^{47}$ revela que, desde o século XVII, $o$ ato de montar a cavalo apresenta-se como uma tradição aristocrática com participação da elite. Para Del Priore ${ }^{40}$, tal costume acaba por " [...] demonstrar um comportamento, uma maneira de se portar, uma pertença" (p.16). Logo, representaçóes acerca da Equitação como um conhecimento especial, um sinal de aptidão e de competência, são construídas.

Aliada a esta questão, a prática do Hipismo, como um esporte de elite e afastada do centro das atençóes dos meios de comunicação de massa ${ }^{46}$, tem seus praticantes atuando em um âmbito esportivo que não deixa de poder ser associado a processos de distinção social (de classe), como destacaria Pierre Bourdieu. Ao longo dos textos nos quais Bourdieu ${ }^{48-50}$, dedicou-se à apreciaçáo do fenômeno esportivo, podem-se enfatizar três questóes de sustentaçáo teórico-metodológicas, a saber: 1) a reflexividade epistemológica; 2) a função do conhecimento histórico nas críticas sociológicas do esporte; e 3) a direção do consumo esportivo no sentido de concretização de um ambiente social associado à lógica de distinçãa ${ }^{51}$. Contudo, os subsídios que Pierre Bourdieu propóe para o incremento do campo científico de análises e estudos direcionados para a sociologia do esporte transcendem seus textos escritos acerca do tema e seus debates sobre as práticas e os consumos esportivos.

Assim, tendo em vista as oposiçóes de práticas equestres de uma maneira mais ampla, podem-se focalizar oposiçóes de filiaçôes sociais a cada uma delas associadas. É o caso, por exemplo, das práticas equestres que compóem o Freio de Ouro, mais ligadas à população predominantemente rural, com elevados recursos financeiros, de vida campesina e de lida campeira e, por outro lado, a prática do Salto do Hipismo conectada, predominantemente, às elites mais urbanas privilegiadas economicamente ${ }^{46}$. Ainda, apreciar os contrastes assinala uma visão panorâmica e um espectro 
distribucional do espaço das práticas equestres: a relação e a comparação de práticas diversas. Por outro lado, a decisão de apontar sensibilidades e gostos confere um segundo requisito teórico: o de vincular cada preferência de prática equestre a um estilo de vida.

Ainda com relação ao espectro de práticas e engajamentos distintos, conforme Bourdieu ${ }^{52}$, o gosto pelas profissões liberais ou pelos cargos superiores tende a orientar-se para o leve, o fino e o refinado, ao contrário do gosto popular, dirigido para o pesado, para o grosso, para o grosseiro. As relaçóes entre cada uma das práticas esportivas associadas às camadas populares, operárias, bem como entre cada uma das práticas relacionadas com as elites econômicas, de ocupantes de cargos superiores e profissionais liberais, são conduzidas por uma expressão: a homologia $^{47}$. No que concerne às práticas equestres, aquelas mais populares (os jóqueis no turfe $\mathrm{e}^{\mathrm{e}}$ nas carreiras de cancha reta ${ }^{\mathrm{u}}$ ) assemelham-se entre si, assim como as práticas equestres de elite (Salto e Polo Equestre). $\mathrm{O}$ espaço dos esportes pode ser compreendido como homológico aos demais espaços sociais; assim, explorá-lo induz-nos a melhor compreender estes espaços. Outro termo confere mais sentido ainda a estas convergências: o "habitus", "subjetividade socializada", ou também "social incorporado", lei "inscrita" nos corpos ${ }^{53}$, dispositivo sociocultural feito corpo, aquele que todas as relaçóes sociais iniciais inserem no organismo para arranjá-lo como uma demarcação de referência que compóe e é composta.

Assim, com a conquista da sede da SHR, uma parcela da elite e de autoridades políticas e militares passaram a ter um local de encontro durante a realização de seus torneios hípicos. A este respeito, em uma reportagem do jornal Diário de Notícias, encontra-se a seguinte passagem: "Realiza-se [...] mais uma das elegantes festas que a Sociedade Hippica Rio Grandense vem offerecendo aos seus sócios e à elite porto-alegrense em geral [...]"21(p.5).

Deste modo, têm-se famílias que, desde aquele período até os dias atuais, se envolviam significativamente com a prática do hipismo e cujos sobrenomes já se faziam presentes no quadro de sócios como praticantes e dirigentes. É o caso, por exemplo, das famílias Chaves Barcellos, Gerdau Johannpeter, Schapke e Chagastelles ${ }^{5-55}$. A tradição familiar aristocrática permeou o universo hípico porto-alegrense desde sua emergência. Consequentemente, capital social simbólico e destaque são atribuídos aos detentores dos sobrenomes realçados pela participação e desempenho neste contexto equestre, em uma associação com os valores nobres e de realeza intrínsecos a este esporte dos reis desde suas origens ${ }^{40,47}$.
Neste cenário, a prática do salto do hipismo, paulatinamente, foi desenvolvendo-se e ocupando outros ambientes não só em Porto Alegre, como em outras cidades do Rio Grande do Sul. O esporte foi organizado a ponto de ocorrer a fundação de novas hípicas na regiāo serrana do Estado, onde muitos imigrantes, principalmente alemães, habitavam ${ }^{56}$.

$\mathrm{Na}$ década de 60, o hipismo sul-rio-grandense apresentava-se em uma nova e importante fase de consolidação e legitimação da prática por meio, especialmente, da estabilização da Sociedade Hípica Porto Alegrense, que promovia muitas competições, além das frequentes "carrières" que eram inauguradas no interior do Estado naquele período. Outra iniciativa que se identificava, na referida década, para melhor preparar o nível técnico dos cavalos e cavaleiros, era a presença de instrutores militares de equitação estrangeiros na mencionada sociedade hípica, especialmente provenientes da Europa ${ }^{57}$. Contudo, concomitantemente, o hipismo segue a ser destacado em reportagens, como na Revista do Globo, como um esporte "exclusivo", "belo e elegante" 58 (p.10), em que apenas algumas dezenas de pessoas, naquele período, praticavam aos domingos, principalmente.

Ainda na década de 60, um importante evento hípico passou a ocorrer anualmente: o Festival Hípico Noturno (FHN). Este campeonato contou, desde o seu início, com integrantes da Brigada Militar, Exército Brasileiro, outras polícias coirmãs, bem como participantes da comunidade civil. Sua criação ocorreu por ocasião da inauguração da "Carrière"v

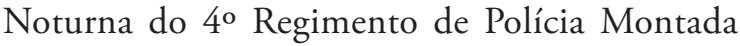
( $\left.4^{\circ} \mathrm{RPMon}\right)$, com a finalidade de promover a integração dos cavalarianos da corporação ${ }^{59}$. Na primeira edição do evento, houve a participação de cavaleiros civis, destacando-se Jorge Gerdau Johannpeter, considerado o melhor cavaleiro civil naquela ocasião ${ }^{60}$.

Com o passar dos anos, o FHN ganhou notoriedade regional e, passou também a ser conhecido internacionalmente ${ }^{59}$. Tal concurso de saltos, idealizado pela Brigada Militar, também conta com o apoio da Federação Gaúcha dos Esportes Equestres (FGEE) e, desde 2007, tornouse, também, uma prova válida pelo Concurso de Saltos Nacional (CSN), segundo publicação do "site" oficial da Brigada Militar ${ }^{61}$. Atualmente, além das tradicionais entidades, o evento congrega as organizaçóes policiais e militares dos países do Cone Sul (nome comumente dado à parte meridional da América do Sul). Assim, é comum, nos últimos anos de realização do FHN, haver participantes oriundos do Uruguai e da Argentina, o que acaba 
corroborando para que este evento se torne, no cenário do hipismo, um grande acontecimento. $\mathrm{O}$ FHN consolidou-se no cenário hípico nacional e internacional, configurando-se como o mais antigo evento hípico noturno do país e o segundo mais importante do hipismo sul-rio-grandense.

Isto porque há um evento hípico sul-rio-grandense de importância ainda maior: trata-se do The Best Jump - Concurso de Saltos Internacional Cidade de Porto Alegre, onde competem alguns dos melhores cavaleiros do mundo, configurando-se como um dos eventos mais relevantes da América Latina, válido como classificatória para a Copa do Mundo de Hipismo e para os Jogos Pan-Americanos ${ }^{62}$. Ao completar 46 anos, em 2014, assim, este evento já se encontra consolidado no circuito nacional e internacional de hipismo. Foi por meio da iniciativa dos admiradores desta prática esportiva que o The Best Jump emergiu em 1969. O maior objetivo era divulgar o hipismo e agregar novos adeptos. A dedicação e a competência de Alcy Resende, Hugo Cipião Ferreira, Oswaldo Lia Pires, Franco Batini, Jorge Gerdau Johannpeter e Sérgio Schapke iniciaram um movimento que gerou a premiação como se conhece hoje. Hoje, o The Best Jumpé referência para praticantes e amantes deste esporte, principalmente devido à melhoria técnica que proporcionou ao hipismo sul-rio-grandense por meio do intercâmbio entre cavalos e cavaleiros de distintos países.

Já no início da década de 70, quando é estabelecido o $3^{\circ}$ Regimento de Cavalaria de Guarda (Regimento Osório), em Porto Alegre, tem-se a concretização de mais três importantes espaços para competiçóes municipais, estaduais e nacionais: a pista de saltos "General Osório" e um campo de polo equestre, inaugurado posteriormente, em 1975, bem como um picadeiro coberto, estabelecido em $1978^{63}$.

Diante disto, já mais ao final da década de 80 , o nível do hipismo sul-rio-grandense já era considerado como bom, conforme reportagem da revista Equusul, enquanto que, concomitantemente, o nível do hipismo nacional era considerado médio ${ }^{64}$. Isto se devia, em grande parte, ao fato de que o hipismo do Rio Grande do Sul, naquele momento, já contava com conjuntos (cavalo e cavaleiro) participando em todos os concursos nacionais e em todas as categorias. Além disto, a presença de um conjunto sul-rio-grandense, dentre os classificados em cada competição, era frequente.

Tal desenvolvimento foi possível, especialmente, em funçáo de um importante trabalho desenvolvido pela FHSRG em 1988: o de intensificar a interiorização do hipismo para não permanecer tão limitado à capital do Estado ${ }^{64}$. A partir de tal medida, passou-se, também, a aproveitar o contato com cavaleiros que participam de campeonatos nacionais e internacionais, estimulando e aumentando o número de competidores neste nível.

Tais fatos, aliados ao já estabelecimento da prática no Rio de Janeiro e São Paulo, sugere um panorama de engajamento regional, nacional e internacional, ao considerar-se, também, o fato de o Hipismo já estar incluído no programa olímpico desde a edição de Paris (França) em 1900, com a concretização de somente três provas. Já nas ediçốes de Saint Louis (Estados Unidos) em 1904 e Londres (Reino Unido) em 1908, o Hipismo esteve afastado, contudo a partir da edição de 1912 em Estocolmo (Suécia) situou-se de vez na agenda da competição ${ }^{3}$.

\section{O hipismo nos jogos olímpicos}

Os Jogos Olímpicos configuram-se como o evento esportivo de ampla repercussão no mundo atual, tanto por sua marca simbólica, pela reapresentação em escala planetária de uma prática que movimenta representaçóes arquetípicas, como pela dimensão material que abarca milhóes de indivíduos direta e indiretamente em seus preparativos e concretização ${ }^{65}$. Conforme Tavares ${ }^{66}$, os Jogos Olímpicos representam a institucionalizaçáo de uma compreensão de práticas que transformam o esporte em uma ação educacional, ética e social, com representaçóes para os indivíduos, as sociedades e as naçôes. Tal perspectiva assinala a importância e a magnitude que os Jogos Olímpicos desempenham como um fenômeno histórico que colaborou significativamente para a propagaçáo de muitos esportes praticados mundialmente. Encontrando-se o Hipismo dentre estes, considera-se a possibilidade de este evento ter tido alguma relação de incentivo, não somente ao estabelecimento de entidades hípicas em Porto Alegre, mas também à caracterização de seus moldes estruturais, a qual culminou com a representação olímpica conferida à cidade atualmente.

O Hipismo náo constava no quadro de esportes dos primeiros Jogos Olímpicos da Era Moderna realizados em Atenas (Grécia) em 1896. No entanto, em 1900, este quadro foi alterado durante os Jogos Olímpicos de Paris, momento em que o Hipismo estreou como demonstração em três provas na categoria de Saltos ${ }^{1}$. Aproximadamente cinco países (Bélgica, França, Estados Unidos da América, Itália e Rússia) tiveram representantes nas provas desta 
edição dos Jogos, denotando uma significativa abrangência desta prática esportiva na esfera mundial, ponderando que o evento em si constituía uma espécie de vitrine para a representação dos esportes considerados olímpicos no mundo. Neste período de estreia do Hipismo nos Jogos Olímpicos, não há registros de existência de alguma entidade ligada ao Hipismo em Porto Alegre e também não houve participação brasileira neste esporte.

Nas ediçốes de Saint Louis, em 1904 e, em Londres, em 1908, o Hipismo esteve ausente, todavia estabeleceu-se definitivamente na agenda da competição a partir de Estocolmo, em 1912, nas competiçôes de Saltos, Adestramento e Concurso Completo de Equitação $(\mathrm{CCE})^{3}$. Por mais de 40 anos, esta prática esportiva e as competiçôes hípicas olímpicas restringiram-se não apenas aos homens, mas também como uma exclusividade absoluta dos militares nos Jogos Olímpicos, em função de a formação deste grupo ser muito específica e de seu contato frequente com a Equitação. Sendo assim, os vencedores eram sempre oficiais graduados, os quais, em pouco mais de 50 anos de competiçóes olímpicas, conquistaram todas as medalhas de ouro. Tal representação militar no contexto deste esporte fez-se perceber notavelmente em Porto Alegre, quando da fundação da já mencionada Escolta Presidencial, em 1916.

Somente após a fundação da Confederaçáa Brasileira de Hipismo (CBH), em 1943 e da Federação Hípica Sul Rio-Grandense (FHSRG), em 1946 - atual Federação Gaúcha de Esportes Equestres - que ocorreu a primeira participação de uma delegação de Hipismo brasileira em Jogos Olímpicos: Londres, no ano de $1948^{67}$. Os brasileiros competiram nas provas de Saltos e no CCE eram todos militares. Segundo indícios encontrados em uma das fontes, nesta equipe de salto estavam, representando o Rio de Janeiro, Renyldo Pedro Guimarães Ferreira e Eloy Massey Oliveira de Menezes; e, de São Paulo, João Franco Pontes e Rubens Continentino Dias Ribeiro ${ }^{3}$. O melhor resultado foi o décimo lugar de João Franco Pontes, com o cavalo Itaguaí. Possivelmente, o maior obstáculo enfrentado por esta equipe composta unicamente por militares, foi a viagem de 32 dias no navio do Lloyd Brasileiro, o qual transportou os cavalos e os cavaleiros até a Europa.

$\mathrm{Na}$ edição seguinte dos Jogos, no ano de 1952, em Helsinque (Finlândia), o Brasil contou com representantes nas provas de Salto e de CCE, novamente. Excelentes resultados foram conquistados nestes Jogos, sendo dois quartos lugares por equipes e individual de saltos, com Eloy Menezes montando o cavalo Biguá. Em uma das fontes encontradas, há a informação de que o coronel da Brigada Militar Gerson Borges teria participado destes Jogos Olímpicos, na categoria Salto, apesar de o Hipismo do Rio Grande do Sul não ser muito desenvolvido na década de 50 , segundo a publicação $0^{68}$. Consta que o coronel Gerson integrava a equipe brasileira formada pelo Coronel Renyldo Ferreira, Álvaro Luciano Dias de Toledo e Eloy Massey Oliveira de Menezes. Contudo, o livro publicado pelo próprio Coronel Renyldo Ferreira, registra que a presença de Gerson Borges, capitão na ocasião, limitou-se a um reforço na equipe, apenas competindo em torneios preparatórios para os Jogos Olímpicos e auxiliando no transporte dos animais pela Europa ${ }^{67}$.

Nos Jogos Olímpicos de Melbourne (Austrália), em 1956, pela primeira vez, os animais e os cavaleiros da equipe brasileira - formada, de forma inédita, também por cavaleiros civis - foram transportados de avião. Um destes cavaleiros era Nelson Pessoa Filho, conhecido pela alcunha "Neco", o qual se tornaria um dos melhores cavaleiros do mundo ${ }^{3}$. Nestes Jogos o melhor resultado foi o décimo lugar na prova de saltos por equipes. Percebe-se que após 50 anos da fundação oficial de uma entidade hípica que congregava civis no Rio Grande do Sul, a Sociedade Hípica Sul Rio-Grandense, que o Brasil passou a contar também com representantes civis em uma equipe de Saltos. Tal fato pode denotar um passo à frente na construção da prática hípica na cidade com relação ao desenvolvimento do Hipismo e exibiçáo para além das fronteiras nacionais: nos Jogos Olímpicos.

O cavaleiro Nelson Pessoa Filho voltaria a participar de competiçóes olímpicas nos Jogos de 1964, em Tóquio (Japão), como o único representante do Brasil, obtendo o quinto lugar na prova de Saltos. Os Jogos de 1968 realizados na cidade do México (México) assinalaram a estreia de uma amazona brasileira em competiçóes olímpicas: Lucia Faria, que, na prova individual, montando o cavalo Rush du Camp, conseguiu o melhor resultado entre os participantes das Américas, o $12^{\circ}$ lugar. Na prova por equipes, reforçada por Nelson Pessoa Filho, que somava a terceira participação em Jogos Olímpicos, o Brasil acabou em sétimo lugar. Este mesmo cavaleiro, em 1972, na cidade de Munique (República Federal da Alemanha na época), em sua quarta edição dos Jogos Olímpicos, não apresentou boa atuação e foi eliminado.

Pela primeira vez desde 1948, o Hipismo nacional não contou com representantes nos Jogos de Montreal (Canadá) em 1976. O mesmo fato ocorreu nos Jogos de Moscou (na ex-União Soviética), em 1980, quando um boicote liderado pelos Estados 
Unidos da América, devido a divergências políticas, acabou resultando na participação de apenas países sem tradição no esporte equestre.

O Brasil retornou aos Jogos de Los Angeles (Estados Unidos) em 1984, somente com a equipe de saltos, que levou uma novidade: o cavalo Alpes, o primeiro de criação nacional a competir em Jogos Olímpicos, da raça Brasileiro de Hipismo. O melhor resultado do Brasil foi o décimo lugar na prova por equipes.

Nos Jogos Olímpicos seguintes, em 1988, em Seul (Coréia do Sul), também contando somente com competidores na modalidade Saltos, o melhor resultado brasileiro foi o oitavo lugar por equipes. Nesta edição, Porto Alegre viu-se representada na equipe brasileira de Saltos por um cavaleiro e por uma amazona: André Bier Gerdau Johannpeter e Christina Harbich Johannpeter, que treinaram na Sociedade Hípica Porto Alegrense.

Já na edição dos Jogos de 1992, em Barcelona (Espanha), 20 anos depois de competir pela quarta vez em Jogos Olímpicos, Nelson Pessoa Filho retornou a competição como um dos integrantes da equipe brasileira de saltos, competindo ao lado do filho, Rodrigo Pessoa, o qual garantiu o nono lugar na prova individual, melhor colocação entre todos os brasileiros. Na prova por equipes, o país classificou-se em sétimo lugar.

André Bier Gerdau Johannpeter representou o Estado na equipe brasileira que conquistou a primeira medalha para o país nos Jogos de 1996, em Atlanta (Estados Unidos da América): bronze por equipes, composta por Rodrigo Pessoa e seu cavalo Tom Boy, Álvaro Miranda Neto (Dodaw), com o cavalo Aspen Joter, Luiz Felipe de Azevedo, com o cavalo Cassiana Joter, além de André Johannpeter, com o cavalo Calei Joter. Na prova individual, o melhor desempenho foi de Doda, com o oitavo lugar.

Nesta competição, a disciplina de Saltos do Hipismo brasileiro competiu com um aspecto inédito: pela primeira vez na história dos Jogos Olímpicos, a equipe teve, em sua maioria, cavalos criados no país, mais especificamente, em Porto Alegre ${ }^{69}$. Três dos quatro cavalos medalhistas de bronze da equipe brasileira (Aspen Joter, Calei Joter e Cassiana Joter) nasceram em Porto Alegre, no Haras Joter ${ }^{69-70}$. A este respeito, na ocasião, o sul-rio-grandense André Johannpeter declarou que tal fato representou o avanço $^{\mathrm{x}}$ do Brasil na modalidade, pois os países europeus possuem haras com até 200 anos de tradição ${ }^{69}$ (p.63). O intuito principal do Haras Joter é democratizar a genética de sua criaçáo, oportunizando o acesso a animais de classe mundial, a fim de promover o esporte. Isto se dá por meio de leilóes em que são ofertados cavalos das principais linhagens da raça de origem alemã Holsteiner, filhos de éguas conhecidas pelos resultados obtidos no esporte, valorizando estes animais propícios à prática do Salto do Hipismo. Cabe destacar que o empresário Jorge Gerdau Johannpeter é o titular do Haras Joter.

Tal apoio e incentivo ao desenvolvimento de uma raça equina para a prática do hipismo já conta com registros desde, pelo menos, a organização da Sociedade Hípica Rio Grandense. Tal entidade, em seus estatutos, publicados no jornal A Federação, assim sintetiza suas atribuiçóes, no artigo $1^{\circ}$ : "A Sociedade Hípica Rio Grandense, de caracter civil, fundada em 19 de novembro de 1925, tem por fim, sem visar lucros materiais de qualquer espécie para os seus sócios, promover o melhoramento da raça cavalar e o desenvolvimento da equitação" ${ }^{\prime 1}$ (p.7).

A família Gerdau Johannpeter está presente no cotidiano hípico, incentivando e investindo no mesmo desde, pelo menos, a década de 30 , quando o alemão naturalizado brasileiro Kurt Johannpeter chegou ao Brasil e casou-se com Helda Gerdau. Desde então, a prática do Hipismo faz parte do cotidiano desta família. A seção hípica do Porto Alegre Country Club e a Sociedade Hípica Porto Alegrense foram os ambientes equestres frequentados regularmente náo somente pelo referido casal, mas também pelos seus filhos Klaus e Jorge Gerdau Johannpeter, bem como pelos filhos deste último, Carlos, André, Karina, Beatriz e Marta Johannpe$\operatorname{ter}^{72}$. A partir destas informações pode-se retomar a noçâo de "habitus" trabalhada por Bourdieu ${ }^{52}$, ao ter em conta que a família constitui o primeiro espaço social com o qual se estabelecem relaçóes.

André Johannpeter, juntamente com Rodrigo Pessoa e o cavalo Baloubet du Rouet, Álvaro Miranda Neto (Doda) com o cavalo Aspen Joter e Luiz Felipe de Azevedo com o cavalo Ralph repetiram a conquista da medalha de bronze por equipe em 2000, nos Jogos Olímpicos de Sidney (Austrália). Além de André Johannpeter, pertencente a uma família de elite econômica que, pelo menos desde o início dos anos 1950, tem ligação com o Hipismo ${ }^{73}$, seu cavalo também era de origem porto-alegrense, o que denota um investimento muito significativo em mais um aspecto condicionante para o esporte na cidade ${ }^{54}$.

$\mathrm{Na}$ ediçáo dos Jogos de 2000, Rodrigo Pessoa esteve muito próximo da medalha olímpica de ouro no Hipismo. Na prova de Salto individual, ele estava na liderança e só precisava zerar o percurso para vencer. Porém, Rodrigo Pessoa e seu cavalo Baloubet 
du Rouet cometeram uma falta em um obstáculo que, teoricamente, era considerado fácil, e o cavalo refugou duas vezes diante de um obstáculo denominado "paralela sobre um rio", fato que causou a eliminação do conjunto. Nesta competição, André Johannpeter, conseguiu a melhor colocação na prova individual: o sexto lugar.

Nos Jogos Olímpicos de Atenas, em 2004, o destaque, foi a histórica conquista de Rodrigo Pessoa na prova individual de Saltos, ao conquistar uma medalha de prata na competição individual e, posteriormente, no ano de 2005, vê-la "transformada" em uma medalha de ouro, quando foi divulgado o "doping" do cavalo do atleta irlandês Cian O'Connor, que havia conquistado o primeiro lugar. $\mathrm{Na}$ prova por equipes, o Brasil conseguiu a décima colocação, com Rodrigo Pessoa e seu cavalo Baloubet du Rouet, Bernardo Alves e o cavalo Canturo, Doda e o cavalo Countdown ${ }^{20}$ e Luciana Diniz ${ }^{y}$ com seu cavalo Mariachi.

Em Pequim (China), nos Jogos de 2008, Rodrigo Pessoa, que já não contou com a parceria de seu cavalo Baloubet de Rouet, conquistou o quinto lugar. Todavia, Camila Mazza, que salta exclusivamente no Brasil, foi a surpresa brasileira com a conquista do $10^{\circ}$ lugar. Ausente do pódio pela primeira vez depois de 12 anos, o Hipismo do Brasil retornou ao país com o trauma de náo poder contar com seus cavalos em períodos cruciais, em função de problemas veterinários encontrados (contusôes durante o transporte até a China ou durante os treinamentos e competiçóes).

Por fim, em 2012, nos Jogos de Londres, Rodrigo Pessoa e Doda progrediram para a final individual. Inclusive, Rodrigo Pessoa, que estava na disputa da sua sexta edição em Jogos Olímpicos, foi o portaestandarte brasileiro na cerimônia de abertura. $\mathrm{Na}$ competiçáo cometeu muitos erros e na classificação final ficou na $22^{a}$ posição. Já Doda, melhor brasileiro na modalidade desde o primeiro dia da competição, conseguiu o $12^{\circ}$ lugar.

Além dos Jogos Olímpicos, nos Jogos Pan-Americanos, ocorreu a participação de sul-rio-grandenses que iniciaram a prática do Hipismo em Porto Alegre. À Brigada Militar, pertenceu o primeiro representante sul-rio-grandense no Hipismo em Jogos Pan-Americanos. Trata-se do coronel Gerson Borges, o qual competiu na Cidade do México (México), em 1975, na prática do Adestramento, conquistando uma medalha de bronze por equipe. Em San Juan (Porto Rico), no ano de 1979, esteve presente novamente, alcançando, desta vez, uma medalha de prata por equipe. Em 1983, nos Jogos
Pan-Americanos de Caracas (Venezuela), Gerson Borges, foi o técnico da equipe ${ }^{3}$.

Novamente, o Rio Grande do Sul só se veria representado no Hipismo na edição dos Jogos Pan-Americanos de 1991 em Havana (Cuba). André Johannpeter participou da conquista de uma medalha de ouro na prática dos Saltos do Hipismo por equipe. Tal feito repetiu-se nos Jogos de 1995 em Mar Del Plata (Argentina), quando André Johannpeter era integrante da equipe brasileira que conquistou mais uma medalha de ouro nos Saltos.

Quando os Jogos Pan-Americanos voltaram a ocorrer em Winnipeg (Canadá), em 1999, o Brasil, mais uma vez, conquistou uma medalha de ouro na prova de Saltos por equipes, com a atuação, novamente, de André Johannpeter. Nos Jogos de Santo Domingo (República Dominicana), em 2003, a irmã de André Johannpeter, Karina Johannpeter, participou da conquista da medalha de bronze para o Brasil, também no Salto por equipes. Esta amazona sul-rio-grandense voltaria a competir nos Jogos Pan-Americanos de 2011, em Guadalajara (México), conquistando uma medalha de prata pela equipe de Saltos.

Importa destacar o fato de que os cavalos com os quais não somente os atletas sul-rio-grandenses, mas também os demais cavaleiros brasileiros participaram de muitas competiçóes são originários do Haras Joter, que existe há 29 anos. Este criatório de cavalos para, principalmente, a prática do Salto do Hipismo, que prepara animais nacionais com nível de desempenho internacional representou um impulso para o hipismo não apenas no Estado, mas no cenário brasileiro.

Tendo em vista a questáo norteadora da pesquisa que buscou compreender como se desenvolveu a prática do Hipismo em Porto Alegre até a primeira participação de atletas sul-rio-grandenses em Jogos Olímpicos, tecemos algumas consideraçôes por meio da análise do "corpus" documental.

A prática do Salto do Hipismo, em Porto Alegre, imprimiu seus primeiros passos oficiais na regiāo por meio da denominada Escolta Presidencial, nova unidade da Brigada Militar, instalada em 1916. Após quase uma década, em 1925, é que se tem registro de uma sociedade promotora deste esporte para o meio civil: a Sociedade Hípica Rio-Grandense. Portanto, identifica-se um pioneirismo militar na prática do Salto do Hipismo em Porto Alegre, bem como o paulatino processo de expansão de sua abrangência, inicialmente mais restrita ao âmbito militar, à parcela civil da sociedade.

Percebe-se que o próprio contexto da prática hípica de Porto Alegre, conforme foi se configurando, 
possibilitou alcançar a representação de atletas nos Jogos Olímpicos. Como referido no texto, muitas características típicas de um esporte moderno já se faziam presentes, mesmo que com certas peculiaridades, no contexto hípico desde os primórdios de sua organizaçáo. Por meio de tal fato, aliado aos demais indícios, como a participação de civis e de mulheres vinculadas às elites econômicas da cidade, bem como, o investimento financeiro de suas famílias denota que Porto Alegre imprimia passos sempre adiante com relação a este esporte olímpico. Por fim, a prática do Hipismo, para além do meio militar, acrescentando homens e mulheres das elites econômicas porto-alegrenses, revela que tal esporte produziu representaçôes de classes sociais privilegiadas economicamente no período estudado. Ainda, os vestígios localizados acerca da origem social de cavaleiros e amazonas envolvidos com a prática do Hipismo em outros lugares do Brasil sugerem uma aproximaçáo da realidade porto-alegrense com o cenário brasileiro.

\section{Notas}

a. A Equitação é definida como "atividades esportivas e de lazer desenvolvidas pelo conjunto ser humano/cavalo, sempre que o primeiro estiver sobre o dorso do segundo" ${ }^{1}$ (p.1).

b. Neste estudo, serão adotadas as nomenclaturas do Comitê Olímpico Brasileiro, o qual denomina por "modalidade" o nome do esporte, como, por exemplo, "hipismo", ao passo que por "disciplina" entende-se o nome da modalidade, como, por exemplo, "salto".

c. Sobre este evento, consultar o estudo de Pereira et al. ${ }^{74}$.

d. Sobre este evento, consultar a pesquisa de Pereira ${ }^{62}$.

e. Tais disciplinas equestres também fazem parte do programa dos Jogos Pan-Americanos.

f. Conforme a Associação Nacional de Jornais (http://www.anj.org.br/maiores-jornais-do-brasil).

g. Jornal reconhecido como contrário à ditadura de Getúlio Vargas. Impulsionou o movimento literário modernista no sul do Brasil e divulgou a Revolução de 1930. No campo do jornalismo, foi inovador na utilização de recursos gráficos e atuou na formação de repórteres na época. Em 1955, o Diário de Notícias cunhou e realizou a Feira do Livro de Porto Alegre, com abertura no dia 17 de novembro, na Praça da Alfândega, localizada na capital. A Feira conserva-se até os dias atuais no calendário anual de Porto Alegre como um de seus eventos mais importantes.

h. É importante realçar que o Correio do Povo se alocava permanentemente como instrumento de anúncio político do regime vigente, um jornal tido como predominantemente conservador, aproximando-se, por exemplo, da figura de Getúlio Vargas no período em que este se encontrava no poder.

i. O primeiro comandante desta nova unidade foi o capitão Lourenço Galante, que, auxiliado por um tenente e um alferes, esteve à frente de um efetivo composto por 87 homens.

j. A Hospedaria para Imigrantes asilava os estrangeiros que, geralmente, eram provenientes da cidade de Santos, no Estado de São Paulo, para serem ali orientados com relação às terras que lhes seriam designadas ${ }^{75}$.

k. No Brasil, o denominado Campeonato do Cavalo D'armas era realizado frequentemente antes da mecanização das unidades hipomóveis do exército brasileiro. De origem europeia, em suas primeiras versôes, tinha como meta preparar os cavalos para combates. Por este motivo, o esporte era conhecido como cavalo d'armas. Os animais deveriam ser ágeis, rápidos, obedientes, resistentes e corajosos. Apesar da mecanização da cavalaria e da escassez das guerras, a prática continuou sendo desenvolvida, principalmente, na Europa, América do Norte, Austrália e Nova Zelândia ${ }^{3}$. Pelo fato de ser disputado apenas por militares, este gênero de competição passou a chamar-se "military" 27 . A primeira competição internacional foi registrada em $1902^{3}$.

1. O Concurso Completo de Equitação figurou, pela primeira vez, no calendário dos Jogos Olímpicos, em 1912 (Estocolmo - Suécia), como um campeonato militar, não admitindo, na competição, em um primeiro momento, cavaleiros civis nem amazonas ${ }^{27}$.

m. Há indícios de que os fundadores da Sociedade Hípica Porto-Alegrense estavam vinculados tanto à Brigada Militar quanto aos civis da elite econômica da capital sul-rio-grandense ${ }^{54}$.

n. Possivelmente, essa regra para a premiação foi inspirada no prêmio Wanderpreiss. O cenário esportivo do remo instaurou este prêmio em 1898, onde para levar o troféu também eram necessárias três vitórias consecutivas ${ }^{76-77}$.

o. O volteio constitui uma atividade acrobática em que um grupo de volteadores, ou um volteador apenas, executam exercícios sobre um cavalo a galope. Esta prática equestre, atualmente, é caracterizada e avaliada por critérios estéticos 
de forma semelhante como ocorre na dança, na ginástica rítmica e na patinação artística ${ }^{78}$. Consiste em uma das mais antigas práticas equestres, podendo resumir-se o volteio como uma ginástica artística sobre o cavalo. Durante a Idade Média, era empregado como parte do treinamento de soldados para as batalhas, com a finalidade de desenvolver o equilíbrio e o entrosamento com o cavalo. Findadas as guerras, o volteio extrapolou os limites dos quartéis e, em seguida, passou a ser praticado em hípicas e pequenos centros de treinamento, espraiando-se pelo mundo. Em 1920, esta prática esportiva equestre foi agregada à programação dos Jogos da Antuérpia; porém, somente em 1983 é que foi reconhecida oficialmente pela Federação Equestre Internacional (FEI $)^{3}$. Atualmente, o volteio não compóe mais o quadro de esportes equestres nos Jogos Olímpicos.

p. Esta competiçẫo também pode ser denominada "steeple-chase", "rallye", Concurso Completo de Equitaçẫo (CCE), ou ainda Three Day Event, uma vez que consiste em três provas diferentes (adestramento, prova de fundo e prova de saltos), as quais ocorrem em três dias consecutivos, parecendo uma prova de triatlo equestre ${ }^{4}$. As duas últimas denominações são oficializadas pela Federação Equestre Internacional (FEI). A prática tem seus primórdios associados aos regimentos de cavalaria, os quais existiam em grande número nos exércitos europeus antes da mecanização das unidades hipomóveis. Consistia em parte dos exercícios rotineiros da tropa e dos oficiais, envolvendo longos percursos de estrada, exercícios sobre terrenos acidentados e largos períodos de galope pelos campos atravessados por obstáculos naturais. Tais exercícios, eventualmente, vieram a constituir disputas entre esquadróes, posteriormente entre regimentos e, mais tarde, entre equipes de cavaleiros de diferentes nacionalidades ${ }^{27}$.

q. Estudos de Melo ${ }^{29,38,79,80}$, Del Priori ${ }^{40}$ e Lucena ${ }^{81}$ apresentam mais dados acerca desta temática.

r. Todavia, os italianos e os alemães também possuíam um significativo gosto pela prática, e muitos dos militares destes países, por conta de seu serviço, demonstravam maestria em Equitação.

s. Para Bourdieu ${ }^{52}$, basicamente, a noção de "cultura" apresenta um significado antropológico, ao assinalar os modos de fazer, sentir e refletir, próprias de um agrupamento humano. De tal modo, todo grupo humano compartilha uma cultura, na medida em que qualquer coletividade forma práticas técnicas, códigos de comportamento e arquiteta uma representação do mundo. A cultura, nesta acepção corrente, assinala os conhecimentos científicos, artísticos, literários de uma pessoa; ela contrapóe o homem erudito ao indivíduo "inculto". Neste caso, os sociólogos discorrem acerca de cultura erudita ou também de cultura "cultivada" ${ }^{22}$ (p.94). Em suma, trata-se da cultura da elite intelectual.

t. Para maiores informaçóes, consultar Pereira et al. ${ }^{72}$.

u. Acerca desta prática, verificar Pereira et al. ${ }^{83}$.

v. Este termo francês refere-se à pista de competiçóes de Hipismo.

w. Doda foi cavaleiro do Centro Hípico de Santo Amaro (fundado em 1935) de São Paulo, o qual configura-se, atualmente, como um dos mais importantes clubes para a prática dos esportes equestres no Brasil.

x. Outro aspecto apontado pelo cavaleiro André Johannpeter, na ocasião da preparação para os Jogos Olímpicos de 1996, foi a participação em concursos internacionais da modalidade, o que contribuiu muito para o aumento do nível técnico dos conjuntos brasileiros e, consequentemente, reforçou o desenvolvimento do Hipismo brasileiro ${ }^{69}$ (p.63).

y. Atualmente, esta amazona está naturalizada como portuguesa e representa Portugal nas competiçôes internacionais.

\section{Abstract}

The first participation of equestrian athletes from Rio Grande do Sul in the Olympic Games

Equestrian practice was introduced in Rio Grande do Sul by the military initiative, later incorporated by civilians. Gradually, Rio Grande do Sul people have begun exceling in this sport competitions. The main question of this historical study is: how has it developed Equestrian practice in Porto Alegre until the first participation of Equestrian athletes from Rio Grande do Sul in the Olympic Games. The documentary analysis of the sources revealed that the first participation of Equestrian athletes from Rio Grande do Sul in the Olympic Games is dated 1988 with the presence of a horseman and a horsewoman, though, since the 1948 edition, there is a team representing Brazil. The winning of Olympic medals in 1996 and 2000 occurred in Brazilian teams including an athlete from Rio Grande do Sul.

KeY Words: Equestrianism; Sport history; Olympic Games; Clubs. 


\section{Referências}

1. Roessler M, Rink B. Esportes hípicos. In: Da Costa L, editor. Atlas do esporte no Brasil. Rio de Janeiro: CONFEF; 2006.

2. Mazo JZ, Assman AB, Dias C, et al. Associaçóes esportivas no Rio Grande do Sul: lugares e memórias. Novo Hamburgo: Feevale; 2012.

3. Vieira S, Freitas A. O que é hipismo. Rio de Janeiro: Casa da Palavra: COB; 2007.

4. Mello MT, Oliveira Filho, CW. Esporte paralímpico. São Paulo: Atheneu; 2012.

5. Burke P. O que é história cultural? Rio de Janeiro: Jorge Zahar; 2005.

6. Pesavento SJ. História \& história cultural. 2a ed. Belo Horizonte: Autêntica; 2008.

7. Booth D. História do esporte: abordagens em mutação. Recorde: Rev Hist Esporte. 2011;4:40.

8. Cuche D. A noção de cultura nas ciências sociais. Bauru: EDUSC; 1999.

9. Torres AS. A campanha nacionalizadora cívico-educativa e a semana da pátria na imprensa de Porto Alegre (1937-1945) [dissertação]. Porto Alegre (RS): PUCRS; 1997.

10. Desportos. In: Mazo JZ. O esporte e a educação física na Revista do Globo: catálogo 1929-1967. Porto Alegre: FEFID/ PUCRS; 2004. 1 CD-ROM.

11. Barros JDA. A fonte histórica e seu lugar de produção. Cad Pesq CDHIS. 2012; 25:23.

12. Bacellar C. Fontes documentais: uso e mau uso dos arquivos. In: Pinski C, organizador. Fontes históricas. São Paulo: Contexto; 2010. p.23-80.

13. Rio Grande do Sul (Estado). Secretaria de Segurança Pública. $4^{\circ}$ RPMon, da Brigada Militar, comemora 93 anos. Porto Alegre: PM5-Imprensa/BM; 2009. Disponível em: http://www.ssp.rs.gov.br/?model=conteudo\&menu=81\&id=11618.

14. Ribeiro AL. Esboço histórico da Brigada Militar do Estado do Rio Grande do Sul. Vol. 2, Agosto de 1918 a setembro de 1930. Porto Alegre: Oficinas gráficas da Brigada Militar; 1953.

15. 4 RPMon. Livro histórico. Porto Alegre: 4º RPMon; [data desconhecida]. [Livro Manuscrito, a partir de 1916].

16. Pimentel, F. Aspectos gerais de Porto Alegre. Porto Alegre: Imprensa Oficial; 1945. v.1.

17. Uma grandiosa e louvável aspiraçáo da Sociedade Hipica Rio Grandense. A Federação. 2 set. 1933:3.

18. Festa hípica. In: Mazo JZ. O esporte e a educaçáo física na Revista do Globo: catálogo 1929-1967. Porto Alegre: FEFID/PUCRS; 2004. 1 CD-ROM.

19. Pereira EL, Mazo JZ. As mulheres nas práticas equestres em Porto Alegre-RS. Hominum. 2014;3:16.

20. Pereira EL, Silva CF, Mazo JZ. Revista do Globo: as mulheres porto-alegrenses nas práticas equestres. Motriz. 2011;17:10.

21. A festa de amanhã. Hippismo Sociedade Hippica Rio-Grandense. Diário de Notícias. 6 jul. 1929: Vida Desportiva.

22. Festa hípica no Country Club: 29/05/1943. In: Mazo JZ.O esporte e a educação física na Revista do Globo: catálogo 1929-1969. Porto Alegre: FEFID/PUCRS; 2004. 1 CD-ROM.

23. A semana do cavallo de guerra: 16/01/1932. In: Mazo JZ. O esporte e a educação física na Revista do Globo: catálogo 1929-1967. Porto Alegre: FEFID/PUCRS; 2004. 1 CD-ROM.

24. Campeonato Nacional de Cavalo D’armas: 23/11/1935. In: Mazo JZ. O esporte e a educação física na Revista do Globo: catálogo 1929-1967. Porto Alegre: FEFID/PUCRS; 2004. 1 CD-ROM.

25. Quinzena desportiva. In: Mazo JZ. O esporte e a educaçáo física na Revista do Globo: catálogo 1929-1967. Porto Alegre: FEFID/PUCRS; 2004. 1 CD-ROM.

26. Monteiro C. Porto Alegre: urbanização e modernidade: a construção social do espaço urbano. Porto Alegre: EDIPUCRS; 1995.

27. Morgado F. Adestramento do cavalo. São Paulo: Nobel; 1990.

28. I Copa de Hipismo Cel. Gerson Borges. Equusul. 1989;1:ago.

29. Melo VA. Remo, modernidade e Pereira Passos: primórdios das políticas públicas de esporte no Brasil. Esporte Soc. 2006;3 [citado 17 jan. 2011]. Disponível em: http://www.uff.br/esportesociedade/pdf/es305.pdf.

30. Sociedade Hippica Rio Grandense: 18/07/1931. In: Mazo JZ. O esporte e a educação física na Revista do Globo: catálogo 1929-1967. Porto Alegre: FEFID/PUCRS; 2004. 1 CD-ROM.

31. Abertura de temporada do corrente anno. Sociedade Hippica Rio-Grandense. Diário de Notícias. 16 jun. 1931: Vida Desportiva, Hippismo: 2.

32. Damo AS. A emergência do associativismo esportivo e do futebol. In: Futebol e identidade social: uma leitura antropológica das rivalidades entre torcedores e clubes. Porto Alegre: Ed. Universidade/UFRGS; 2002. p.16-32.

33. Já Editores. História ilustrada de Porto Alegre. Projeto enquadrado na Lei Estadual 10.846, de estímulo à produção cultural. Porto Alegre: Secretaria de Estado da Cultura do Rio Grande do Sul; 1997.

34. Melo VA. Das touradas às corridas de cavalo e regatas: primeiros momentos da configuração do campo esportivo no Brasil. In: Del Priore M, Melo VA, organizadores. História do esporte no Brasil: do império aos dias atuais. São Paulo: UNESP; 2009. p.35-70.

62 • Rev Bras Educ Fís Esporte, (São Paulo) 2015 Jan-Mar; 29(1):47-64 
35. Mazo JZ. Emergência e a expansão do associativismo desportivo em Porto Alegre (1867-1945): espaço de representação da identidade cultural teuto-brasileira [tese]. Porto (PT): Universidade do Porto, Faculdade de Educação Física e Ciências do Desporto; 2003.

36. Confederação Brasileira de Hipismo. Nasce a Confederação Brasileira de Hipismo. [citado 13 abr. 2010]. Disponível em: http://www.cbh.org.br/site/cbh_historico.php.

37. Amaro Junior JF. Marcante progresso obteve o hipismo no Rio Grande do Sul, no ano de 1946. Almanaque Esportivo do Rio Grande do Sul. Porto Alegre: Tipografia do Centro; [1947?]. p.183-5.

38. Melo VA. Mulheres em movimento: a presença feminina nos primórdios do esporte na cidade do Rio de Janeiro (até 1910). Rev Bras História. 2007;27:127-52 [citado 17 jan 2011]. Disponível em: http://redalyc.uaemex.mx/ pdf/263/26305410.pdf.

39. Adelman M. Mulheres atletas: re-significações da corporalidade feminina. Estud Fem. 2003;2:20.

40. Del Priore M. "Jogos de cavalheiros": as atividades físicas antes da chegada do esporte. In: Del Priore M, Melo V, editores. História do esporte no Brasil: do império aos dias atuais. São Paulo: UNESP; 2009. p.20.

41. Gordinho M, coordenador. Sociedade Hípica Paulista: 75 anos. São Paulo: Marca d’Água; 1987.

42. Santos RP. Tensões na consolidação do futebol nacional. In: Del Priore M, Melo V, organizadores. História do esporte no Brasil: do império aos dias atuais. São Paulo: UNESP; 2009. p.179-212.

43. Elias N, Dunning E. A busca da excitação. Lisboa: Difel; 1992.

44. Week-end na serra: 31/03/1951. In: Mazo JZ. O esporte e a educação física na Revista do Globo: catálogo 1929-1967. Porto Alegre: FEFID/PUCRS; 2004. 1 CD-ROM.

45. O crystal foi o local escolhido para a festa de amanhã/Sociedade Hippica Rio Grandense. Diário de Notícias. 28 abr 1929: Vida Desportiva.

46. Adelman M. Mulheres no esporte: corporalidades e subjetividades. Movimento. 2006;12:11-29.

47. Vigarello G. Exercitar-se, jogar. In: Corbin A, Courtine J, Vigarello G, editores. História do corpo: da Renascença às Luzes. Orth LME, tradutor. Petrópolis: Vozes; 2008.

48. Bourdieu P. Sport and social class. Soc Sci Inform. 1978;17:21.

49. Bourdieu P. Como é possível ser esportivo? Questôes de sociologia. Rio de Janeiro: Marco Zero; 1983. p.33.

50. Bourdieu P. Programa para uma sociologia do esporte. Coisas ditas. São Paulo: Brasiliense; 1990. p.13.

51. Souza J, Marchi Júnior W. Por uma sociologia reflexiva do esporte: consideraçóes teórico-metodológicas a partir da obra de Pierre Bourdieu. Movimento. 2010;16:22.

52. Bourdieu P. O habitus e o espaço dos estilos de vida. In: Bourdieu P. A distinção: crítica social do julgamento. Porto Alegre: Zouk; 2007.

53. Bourdieu P. Sport, classes sociales et subcultures, conférence introductive. Paris: INSEP; 1984.

54. André Bier Johannpeter: álbum 70 anos da Sociedade Hípica Porto Alegrense. Porto Alegre: [editora desconhecida]; 2009.

55. Sociedade Hipica Rio Grandense. Diário de Notícias. 5 mai 1929: Vida Desportiva, Hipismo:5.

56. Festa na serra: 10/03/1945. In: Mazo, JZ. O esporte e a educação física na Revista do Globo: catálogo 1929-1967. Porto Alegre: FEFID/PUCRS; 2004. 1 CD-ROM.

57. Osório L. Bety Belmonte: hipismo também é show. 01\%07/1965. In: Mazo JZ. O esporte e a educação física na Revista do Globo: catálogo 1929-1967. Porto Alegre: FEFID/PUCRS; 2004. 1 CD-ROM.

58. Carneiro F. É domingo em Porto Alegre. 15/12/1966. In: Mazo JZ. O esporte e a educação física na Revista do Globo: catálogo 1929-1967. Porto Alegre: FEFID/PUCRS; 2004. 1 CD-ROM.

59. Fagundes Junior, JDG. Festival Hípico Noturno de Porto Alegre: os primórdios de um evento equestre na cidade [monografia]. Porto Alegre (RS): Universidade Federal do Rio Grande do Sul, Escola de Educação Física; 2010. [citado 26 nov 2013]. Disponível em: http://www.lume.ufrgs.br/bitstream/handle/10183/27736/000766490.pdf?sequence=1.

60. Encerrado sábado à noite com grande brilhantismo: I Festival Hípico promovido pelo Regimento Bento Gonçalves. Correio do Povo. 19 dez. 1960: Folha Esportiva: 3.

61. Rio Grande do Sul (Estado). Brigada Militar. História do festival Hípico Noturno. [citado 1 nov. 2010]. Disponível em: www.brigadamilitar.rs.gov.br/fhn.

62. Pereira EL. As práticas equestres em Porto Alegre: percorrendo o processo da esportivização [dissertação]. Porto Alegre (RS): Universidade Federal do Rio Grande do Sul, Escola de Educação Física; 2012.

63. $3^{\circ}$ Regimento de Cavalaria de Guarda. Regimento Osório. Histórico RGT Osório: síntese histórica do Regimento Osório. [citado 15 jul. 2014]. Disponível em: http://www.lw135349918050acc497.hospedagemdesites.ws/site/index. php?option=com_content\&task=view\&id=42\&Itemid=60. 
64. O nível do Sul. Equusul. 1989;1: ago.

65. Rubio K. Os Jogos Olímpicos e a transformação das cidades: os custos sociais de um megaevento. Scripta Nova. 2005 ;9.

66. Tavares O. Referenciais teóricos para o conceito de Olimpismo. In: Tavares O, Da Costa L, editores. Estudos olímpicos. Rio de Janeiro: Gama Filho; 1999.

67. Ferreira R. História do hipismo brasileiro. São Paulo: Design; 2007.

68. Laços de família: recordar é viver. Santo Amaro a Galope. 2010:12.

69. Bandeira C. André Johannpeter tenta vaga na Europa. Zero Hora. 5 mai 1996.

70. Roehe C. Equipe de hipismo leva cavalos brasileiros. Zero Hora. 9 jul. 1996.

71. Estatutos da Sociedade Hipica Rio Grandense. A Federação. 1933.

72. Pereira EL, Silva CF, Mazo JZ. O turfe em Porto Alegre/Rio Grande do Sul: aspectos históricos de uma prática cultural esportiva. Lecturas Educación Física y Deportes. 2010;150:1-15. [citado 17 jan 2011]. Disponível em: http://www. efdeportes.com/efd150/o-turfe-aspectos-historicos-de-uma-pratica-esportiva.htm.

73. Uma tarde hípica: 31/03/1951. In: Mazo JZ. O esporte e a educação física na Revista do Globo: catálogo 1929-1967. Porto Alegre: FEFID/PUCRS; ESEF/UFRGS; 2004. 1 CD-ROM.

74. Pereira EL, Fagundes Junior JDG, Mazo, JZ. Festival hípico noturno de Porto Alegre: os primórdios de um evento equestre na cidade. 21. Congresso Científico de Educação Física; 2011; Tramandaí, BR. Novo Hamburgo: Feevale; 2011.

75. Porto Alegre (Cidade). Prefeitura Municipal. Secretaria Municipal da Cultura. Memória dos bairros: Cristal. Porto Alegre: Unidade Editorial da Secretaria Municipal da Cultura; 2003.

76. Silva C, Mazo, J. Grêmio de Regatas Almirantes Tamandaré: memórias da fundação do primeiro clube de remo "brasileiro" em Porto Alegre (1903-1923). Rev Arq Movimento. 2009;5.

77. Silva CF, Pereira EL, Mazo JZ. Grêmio de Regatas Almirante Tamandaré: uma ameaça ao império identitário teutobrasileiro no cenário do remo porto-alegrense. Movimento. 2014;20:10.

78. Almeida JJG, Weller, MJ. A história do volteio. V Encontro de História do Esporte, Lazer e Educação Física; 1997; Maceió, BR. Maceió: UFTAL; 1997.

79. Melo VA. Possíveis representaçóes sobre o turfe na sociedade carioca do século XIX. Lect Educ Fís Deportes. 1998;3. [citado 17 jan 2011]. Disponível em: http://www.efdeportes.com/efd9/turf91p.htm.

80. Melo VA. Cidade sportiva: primórdios do esporte no Rio de Janeiro. Rio de Janeiro: Relume Dumará/FAPERJ; 2001.

81. Lucena R. O esporte na cidade: aspectos do esforço civilizador brasileiro. Campinas: Autores Associados; 2001.

82. Bonnewitz P. Primeiras liçôes sobre a sociologia de P. Bourdieu. Petrópolis: Vozes; 2003.

83. Pereira EL, Lyra VB, Mazo JZ. Corridas de cavalo em cancha reta em Porto Alegre (1852/1877): uma prática culturalesportiva sul-rio-grandense. Rev Educ Fís/UEM. 2010;21 [citado 6 mai 2011]. Disponível em: http://periodicos.uem. br/ojs/index.php/RevEducFis/article/viewFile/8164/6770.

ENDEREÇO

Carolina Fernandes da Silva

Av. Lucas de Oliveira, 1659 - apto. 202 90460-001 - Porto Alegre - RS - BRASIL e-mail: carol_ed.fis@hotmail.com
Recebido para publicação: 20/06/2013

1a. Revisão: 14/11/2013

2a. Revisão: 30/07/2014

Aceito: 13/10/2014 